\title{
Usual gait speed assessment in middle-aged and elderly Brazilian subjects
}

\author{
Velocidade usual da marcha em brasileiros de meia idade e idosos
}

\author{
Rômulo D. Novaes', Aline S. Miranda², Victor Z. Dourado³
}

\begin{abstract}
Objectives: To evaluate the usual gait speed of asymptomatic adult and elderly Brazilians with a 10-meter walk test and to compare the results with foreign reference values. Methods: Seventy-nine asymptomatic volunteers $\geq 40$ years old of both genders were assessed. After anamnesis, anthropometry and the application of a habitual physical activity questionnaire, the volunteers were submitted to a 10-meter walk test at usual speed by means of which gait speed, the number of steps and length of stride were calculated. Results: Except for age, all study variables were significantly lower in women. Subjects $\geq 70$ years old presented a significantly lower gait speed than subjects between 40 and 49 years old and between 50 and 59 in both men $(1.09 \pm 0.18 \mathrm{~m} / \mathrm{s}, 1.35 \pm 0.11 \mathrm{~m} / \mathrm{s}$ and $1.34 \pm 0.22 \mathrm{~m} / \mathrm{s}$, respectively) and women $(1.02 \pm 0,10 \mathrm{~m} / \mathrm{s}, 1.27 \pm 0.20 \mathrm{~m} / \mathrm{s}$ and $1.27 \pm 0,15 \mathrm{~m} / \mathrm{s})$, respectively). Gait speed showed moderate correlations with age $(r=-0.41, p<0.001)$ and height $(r=0.35, p=0.001)$. After multiple regression analysis, age and gender were selected as relevant attributes of gait speed in that they explained $24.6 \%$ of this variable. The gait speed values in this study were significantly lower than foreign reference values $(p<0.05)$. Conclusions: The gait speed presented age-related decline and values significantly lower than those described for foreign populations. This finding indicates the need for comprehensive investigation of gait speed reference values for the Brazilian population.
\end{abstract}

Key words: gait kinematics; gait speed; 10-meter walk test.

\section{Resumo}

Objetivos: Avaliar a velocidade usual da marcha (VM) por meio de teste de caminhada de $10 \mathrm{~m}$ (TC10m) em adultos e idosos assintomáticos brasileiros e compará-la com os valores de referência estrangeiros. Métodos: Setenta e nove voluntários assintomáticos com idade $\geq 40$ anos, de ambos os gêneros, foram avaliados. Após anamnese, antropometria e questionário de atividade física habitual, os voluntários foram submetidos ao TC10m em velocidade usual. Por meio do tempo de teste, a VM, o número e comprimento dos passos e das passadas foram calculados. Resultados: Com exceção da idade, todas as variáveis estudadas foram significativamente inferiores para as mulheres. Os indivíduos com idade $\geq 70$ anos apresentaram VM significativamente inferior aos indivíduos entre 40 e 49 anos e entre 50 e 59 anos nos homens $(1,09 \pm 0,18 \mathrm{~m} / \mathrm{s}, 1,35 \pm 0,11 \mathrm{~m} / \mathrm{s}$ e 1,34 $\pm 0,22 \mathrm{~m} / \mathrm{s}$, respectivamente) e nas mulheres $(1,02 \pm 0,10 \mathrm{~m} / \mathrm{s}, 1,27 \pm 0,20 \mathrm{~m} / \mathrm{s}$ e 1,27 $\pm 0,15 \mathrm{~m} / \mathrm{s}$, respectivamente). A VM apresentou correlações moderadas com a idade ( $r=-0,41$, $p<0,001)$ e com a estatura $(r=0,35, p=0,001)$. Após análise de regressão múltipla, idade e gênero foram selecionados como atributos determinantes da VM, explicando 24,6\% dessa variável. Os valores da VM encontrados foram significativamente inferiores aos valores de referência estrangeiros $(p<0,05)$. Conclusões: A VM apresentou declínio com o avançar da idade e valores significativamente inferiores àqueles descritos para populações estrangeiras. Esse achado indica a necessidade de ampla investigação dos valores de referências da VM para a população brasileira.

Palavras-chave: cinemática da marcha; velocidade da marcha; teste de caminhada de 10m.

Received: 24/03/2010 - Revised: 14/06/2010 - Accepted: 14/12/2010

\footnotetext{
Postgraduate Program in Cell and Structural Biology, Universidade Federal de Viçosa (UFV), Viçosa, MG, Brazil

${ }^{2}$ Postgraduate Program in Health Science, Infectious Diseases and Tropical Medicine, Universidade Federal de Minas Gerais (UFMG), Belo Horizonte, MG, Brazil

${ }^{3}$ Department of Health Science, Universidade Federal de São Paulo (UNIFESP), Santos, SP, Brazil

Correspondence to: Victor Z. Dourado, Universidade Federal de São Paulo (UNIFESP), Campus Baixada Santista, Av. Alm. Saldanha da Gama, 89, CEP 11030-400, Santos, SP, Brasil,

e-mail: vzdourado@yahoo.com.br; victor.dourado@unifesp.br
} 


\section{Introduction $: \therefore$.}

The measurement of physical mobility is an essential component of the clinical assessment of both geriatric patients and those with neuromotor disorders ${ }^{1-7}$. However, this procedure is not widely adopted due to time and physical space requirements and the need for sophisticated equipment ${ }^{8,9}$. Another contributing factor to the underuse of physical mobility tests is the lack of reference values, especially for the Brazilian population.

Among physical mobility tests, usual gait speed is a simple and quick measurement that is easily obtained in either a clinical setting or at home and does not require sophisticated equipment ${ }^{5}$. The usual gait speed evaluation has been used in studies evaluating balance and physical mobility both before, during and after programs of functional rehabilitation in patients with stroke sequelae ${ }^{10-12}$. Usual gait speed can be easily obtained by requesting the individual to walk at normal speed on a flat surface for a predetermined distance (usually between 6 and $15 \mathrm{~m}$ ). The only equipment necessary for this evaluation is a tape measure to plot the walkway and a stopwatch to record the time ${ }^{13}$.

A 6 to $15 \mathrm{~m}$ walk test shows good reliability and reproducibility and is valid for assessing physical mobility in either a clinical setting or at home ${ }^{14}$. Usual gait speed is associated with general health status as well as anthropometric, physical, psychological and social characteristics ${ }^{9,11}$, and it can be used as an indicator of physiological reserve and as a prognostic factor for the risk of falls, frailty, institutionalization and death in geriatric patients ${ }^{5,6,10,15-18}$. It has been shown that a reduction of $0.1 \mathrm{~m} / \mathrm{s}$ in gait speed increases the risk of falls $7.0 \%$ in the elderly ${ }^{14}$ and that an improvement in gait speed maintained for one year reduces the absolute risk of death by $17.7 \%^{18}$. Moreover, the measurement of gait speed is considered a simple and effective measure for evaluating the functional capacity of elderly people. This evaluation should be considered both before and after interventions, since alterations in kinetic and kinematic aspects of gait are potentially modifiable in programs of physical rehabilitation ${ }^{5,18}$.

Although a number of authors have used the walk test to obtain subjects' usual gait speed, the literature offers little consensus regarding reference values and test standardization $^{13,19-21}$.

Due to the scarcity of such reference values and standardization, especially regarding the Brazilian population, this study aimed to evaluate which demographic and anthropometric attributes influence usual gait speed in a Brazilian population and to compare these results with foreign reference values.
Methods : $:$.

\section{Subjects}

Seventy-nine healthy and sedentary 40-year-old volunteers of both genders were evaluated. All volunteers had a normal joint range of motion. The consumption of substances that could interfere in usual gait speed as well as evidence of cardiovascular, osteoarticular, neuromuscular or metabolic involvement that might prevent or alter usual gait speed were considered as exclusion criteria for this study. All volunteers were clearly informed about the procedures involved in the study and signed an informed consent form. The study was approved by the Committee on Ethics in Human Research of the Universidade Federal de São Paulo (UNIFESP), Santos, SP, Brazil (protocol 1623/07). After anamnesis and measurement of body weight, height, blood pressure and heart rate, the volunteers underwent the following evaluations:

\section{Evaluation of habitual physical activity level}

The Baecke, Burema and Frijters ${ }^{22}$ questionnaire was the instrument used to assess the level of habitual physical activity. It is composed of three domains: the first refers to the individual's level of occupational physical activity, the second to sporting activity and the third to leisure activity. This study included only individuals who obtained a total score $\leq 8$, which indicates a sedentary lifestyle.

\section{Ten-meter walk test}

The $10 \mathrm{~m}$ walk test (10mWT) was the tool used to evaluate the spatial, temporal, and kinematic attributes of gait ${ }^{13}$. To eliminate the acceleration and deceleration components, the volunteers were instructed to begin walking $1.2 \mathrm{~m}$ before the beginning of the course and to finish $1.2 \mathrm{~m}$ after the end of the course at usual speed (Figure 1). Three tests were carried out to minimize the learning effect, and the best performance was used for data analysis. A single examiner using a digital stopwatch with a $1 / 100$ of a second reading (Cronobio SW$2018^{\circ}$, Pastbio, SP, Brazil) recorded the walking time of all volunteers and registered the number of steps and strides taken during the course. Using these data the speed, gait cadence and step and stride length were estimated.

The volunteers received the following standardized instructions from the examiner: "Do you see that mark 10 $\mathrm{m}$ in front of you?"; "Please walk $1.2 \mathrm{~m}$ past that mark at 
your usual speed"; "Please start walking as soon as you are ready”.

\section{Statistical analysis}

Statistical analysis was carried out using the statistical package SigmaStat $3.1^{\circ}$. The following tests were performed: Kolmogorov-Smirnov to evaluate the normality of the variables; descriptive analysis of the data with the values presented as means \pm standard deviation; Student's $t$-test to compare mean values (e.g., between men and women); ANOVA to compare the mean values among age groups (40-49; 50-59; 60-69, $\geq 70)$; the Pearson correlation coefficient to evaluate correlations of usual gait speed with age, body mass, height and BMI, and finally multiple regression analysis to assess the influence of gender, height, body mass and age on usual gait speed.

Additionally, the mean values obtained for usual gait speed were compared with those predicted for foreign populations. To accomplish this, two studies widely cited in the literature were used ${ }^{19,23}$. For each study, a straight-line equation determining usual gait speed as a function of age and height for each gender was calculated. After determining the equation, 79 random theoretical values of age $(\geq 40$ yrs) and height for each gender were used in formulas to provide gross values of usual gait speed. Finally, these values were compared to the results of the present study with two-way ANOVA followed by Bonferroni post hoc. Values of $\mathrm{p}<0.05$ were considered statistically significant.

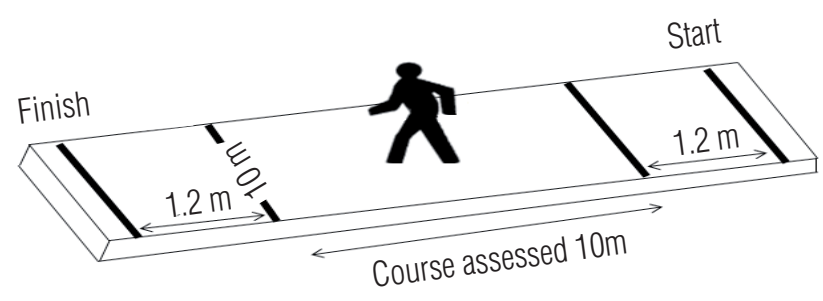

Figure 1. Representative diagram of the 10-meter walk test.

Results : $:$.

\section{General characteristics and spatial and temporal attributes of gait}

As can be observed in Table 1, of the 79 volunteers, 43 (54.43\%) were men. There were no significant differences in age between men and women $(p>0.05)$. Mean values of height, body mass, stride length, step length and usual gait speed were significantly higher for men in all investigated age groups $(\mathrm{p}<0.05)$, while the number of steps and strides was significantly higher for women in all age groups $(\mathrm{p}<0.05)$.

The mean values of usual gait speed observed in this study for both genders and all age groups were significantly lower $(\mathrm{p}<0.05)$ than those described in foreign literature (Table 2).

Table 1. General characteristics and spatial and temporal values of gait in the study sample according to gender and age groups.

\begin{tabular}{lcccccccccc}
\hline $\begin{array}{l}\text { Age } \\
\text { groups }\end{array}$ & $40-49$ & $50-59$ & $60-69$ & $\geq 70$ & Total & $40-49$ & $50-59$ & $60-69$ & $\geq 70$ & Total \\
\cline { 3 - 11 }$n$ & 9 & 13 & 11 & 10 & 43 & 11 & 8 & 9 & 8 & 36 \\
\hline Age (years) & $45.0 \pm 3.0$ & $54.0 \pm 4.0$ & $64.0 \pm 3.0$ & $74.0 \pm 3.0$ & $59.0 \pm 10.0$ & $43.0 \pm 2.0$ & $53.0 \pm 3.0$ & $65.0 \pm 2.0$ & $73.0 \pm 3.0$ & $57.0 \pm 12.0$ \\
\hline Height (cm) & $174.0 \pm 11.0$ & $175.0 \pm 5.0$ & $172.0 \pm 5.0$ & $168.0 \pm 5.0$ & $172.0 \pm 7.0$ & $163.0 \pm 10.0$ & $167.0 \pm 8.0$ & $153.0 \pm 5.0$ & $153.0 \pm 8.0$ & $159.0 \pm 10.0^{*}$ \\
\hline $\begin{array}{l}\text { Body Mass } \\
\text { (kg) }\end{array}$ & $76.0 \pm 14.0$ & $83.0 \pm 13.0$ & $69.0 \pm 7.0$ & $72.0 \pm 13.0$ & $76.0 \pm 13.0$ & $66.0 \pm 8.0$ & $70.0 \pm 12.0$ & $65.0 \pm 10.0$ & $66.0 \pm 10.0$ & $66.0 \pm 10.0^{*}$ \\
\hline $\begin{array}{l}\text { Number of } \\
\text { strides }\end{array}$ & $6.7 \pm 0.6$ & $7.0 \pm 0.6$ & $6.1 \pm 0.5$ & $6.7 \pm 0.8$ & $6.7 \pm 0.7$ & $7.8 \pm 0.6$ & $7.6 \pm 0.5$ & $7.8 \pm 0.6$ & $7.8 \pm 0.6$ & $7.7 \pm 0.6^{*}$ \\
\hline SL (cm) & $148.0 \pm 14.0$ & $141.0 \pm 13.0$ & $163.0 \pm 14$ & $148.0 \pm 16.0$ & $150.0 \pm 16.0$ & $127.0 \pm 10.0$ & $130.0 \pm 10.0$ & $128 \pm 10.0$ & $127.0 \pm 10.0$ & $128.0 \pm 10.0^{*}$ \\
\hline $\begin{array}{l}\text { Number of } \\
\text { Steps }\end{array}$ & $13.4 \pm 1.2$ & $14.1 \pm 1.3$ & $13.0 \pm 1.1$ & $14.2 \pm 1.7$ & $13.7 \pm 1.4$ & $15.6 \pm 1.2$ & $15.2 \pm 1.1$ & $15.9 \pm 1.5$ & $16.2 \pm 1.3$ & $15.7 \pm 1.3^{*}$ \\
\hline LS (cm) & $74.0 \pm 7.0$ & $70.0 \pm 6.0$ & $76.0 \pm 6.0$ & $70.0 \pm 7.0$ & $73.0 \pm 7.0$ & $63.0 \pm 5.0$ & $65.0 \pm 5.0$ & $62 \pm 6.0$ & $61.0 \pm 5.0$ & $63.0 \pm 5.0^{*}$ \\
\hline GS (m/s) & $1.35 \pm 0.11$ & $1.34 \pm 0.22$ & $1.26 \pm 0.15$ & $1.09 \pm 0.18$ & $1.26 \pm 0.20$ & $1.27 \pm 0.20$ & $1.27 \pm 0.15$ & $1.07 \pm 0.17$ & $1.02 \pm 0.10$ & $1.16 \pm 0.20^{*}$
\end{tabular}

SL=stride length; $L S=$ Iength of step; GS=gait speed. ${ }^{*} p<0.05$ : men vs. women (Student's t-test) 
Table 2. Comparison between the mean values of gait speed $(\mathrm{m} / \mathrm{s})$ found in this study with those predicted for foreign populations.

\begin{tabular}{lcccccc}
\hline \multirow{2}{*}{ Age group (years) } & \multicolumn{2}{c}{ Öberg et al. ${ }^{19}$} & \multicolumn{2}{c}{ Bohannon $^{23}$} & \multicolumn{2}{c}{ This study } \\
& Men & Women & Men & Women & Men & Women \\
\hline $40-49$ & $1.33 \pm 0.10$ & $1.25 \pm 0.14$ & $1.46 \pm 0.16^{\mathrm{a}}$ & $1.39 \pm 0.16^{\mathrm{a}}$ & $1.35 \pm 0.11^{\mathrm{b}}$ & $1.27 \pm 0.20^{\mathrm{b}}$ \\
\hline $50-59$ & $1.25 \pm 0.18^{\mathrm{a}}$ & $1.11 \pm 0.60^{\mathrm{a}}$ & $1.39 \pm 0.23$ & $1.40 \pm 0.15^{\mathrm{a}}$ & $1.34 \pm 0.22^{\mathrm{b}}$ & $1.27 \pm 0.15^{\mathrm{b}}$ \\
\hline $60-69$ & $1.28 \pm 0.12$ & $1.16 \pm 0.17^{\mathrm{a}}$ & $1.36 \pm 0.21^{\mathrm{a}}$ & $1.30 \pm 0.21^{\mathrm{a}}$ & $1.26 \pm 0.15^{\mathrm{b}}$ & $1.07 \pm 0.17^{\mathrm{b}}$ \\
\hline $70-79$ & $1.18 \pm 0.15^{\mathrm{a}}$ & $1.11 \pm 0.13^{\mathrm{a}}$ & $1.33 \pm 0.2^{\mathrm{a}}$ & $1.27 \pm 0.21^{\mathrm{a}}$ & $1.09 \pm 0.18^{\mathrm{b}}$ & $1.02 \pm 0.10^{\mathrm{b}}$ \\
\hline
\end{tabular}

a,b superscript letters indicate significant differences between means $(p<0.05)$ according to the corresponding gender and age group. Two-way ANOVA and Bonferroni post-hoc test. The Öberg et al. ${ }^{19}$, and Bohannon ${ }^{23}$, studies were not compared.

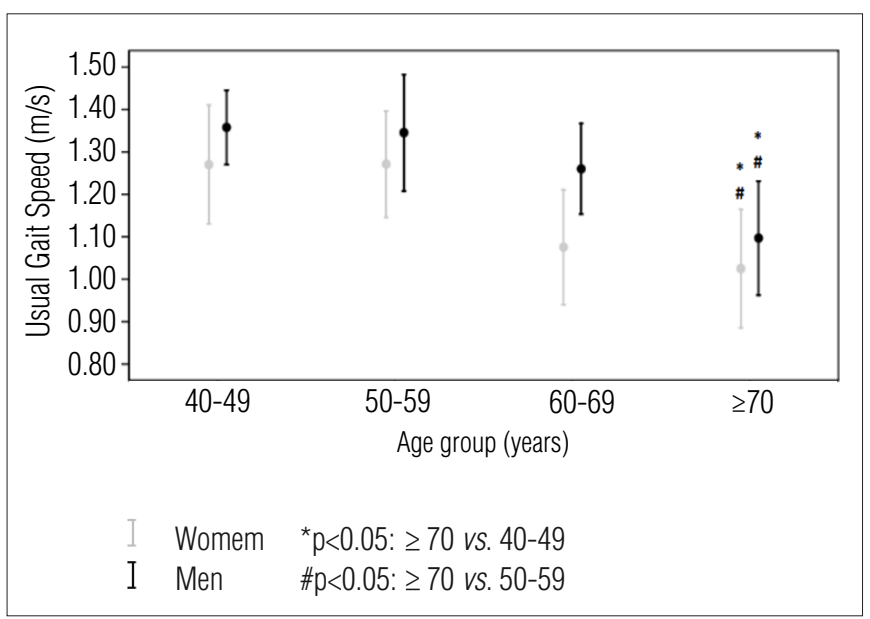

Figure 2. Behavior of usual gait speed according to gender and age groups. Data are shown as means and confidence intervals.

Figure 2 displays gait speed between genders by age group. In contrast to what was observed for general means, there were no significant gender differences in any age group. A decline in usual gait speed was apparent with advancing age in both genders. Individuals $\geq 70$ years old demonstrated significantly lower mean values of usual gait speed than individuals 40 to 49 or 50 to 59 years old in both genders $(\mathrm{p}<0.05)$.

\section{Correlation and multiple regression analysis}

Usual gait speed showed moderate correlations with age $(\mathrm{r}=-0.41, \mathrm{p}<0.001)$ and height $(\mathrm{r}=0.35, \mathrm{p}=0.001)$. No significant correlations between usual gait speed and leg length or body mass were observed. After the multiple regression analysis, age and gender were selected as the determinant attributes of usual gait speed in that they explained $24.6 \%$ of this variable (Table 3 ).

\section{Discussion $: \because$.}

In the present study, a significant decline in usual gait speed was observed with increasing age. This decline seemed to be more significant in the older age group. Moreover, age and gender influenced usual gait speed $\left(R^{2}=0.246\right)$, although this $R^{2}$ value indicated the need to include other variables in the regression model to adequately estimate this variable. Age has been described as one of the principal factors in the determination of usual gait speed in healthy individuals, and invariably it is included in the best mathematical models for predicting gait speed ${ }^{19,20,23}$. The correlation between age and usual gait speed is well-established and gradually reduces with age ${ }^{6,9,19,20}$. This behavior is related to alterations in senescence, such as a greater tendency to inactivity, reductions in muscle mass and the number and function of motor units and increased reaction time and latency of phasic contractions of lower-limb muscles ${ }^{2-4,21,24-27}$.

The present study showed, using a simple and low-cost method, that usual gait speed declines with age and that those $\geq 70$ years old show significant reductions in usual gait speed compared to those between 40 and 59 years old, regardless of gender. However, there was no significant difference in usual gait speed among individuals between 60-69 and $\geq 70$ years old in either gender. A decline in gait speed associated with increased age has been observed in previous studies using computerized image analysis ${ }^{3,28,29}$. Murray, Kory and Clarkson $^{28}$ evaluated 64 individuals between 20 and 87 years old who were divided into five-year age groups and noticed that usual gait speed was significantly lower in the three higher age groups than the lowest age group.

Although limited, the influence of variables such as age and gender on usual gait speed $\left(\mathrm{R}^{2}=0.246\right)$ is apparent. In fact, several other factors significantly influence this variable ${ }^{2-6}$. ,9,18,26,27,30-32. Using similar methodology to the present study, Woo, Ho and $\mathrm{Yu}^{30}$ followed 559 men and 612 women $\geq 70$ years old for 36 months and observed that usual gait speed, stride length, age and gender were the main determinants of dependence level (Barthel Index) and mortality. Stride length was the only variable selected as determinant of institutionalization ${ }^{30}$. Furthermore, Cesari et al. ${ }^{31}$, using a $6 \mathrm{~m}$ walking test, showed that older individuals ( $n=3047$ ) with a usual gait speed of $<1 \mathrm{~m} / \mathrm{s}$ had a higher prevalence of lower-limb neuromotor limitations and hospitalizations than individuals with a gait speed $\geq 1 \mathrm{~m} / \mathrm{s}$. In fact, usual gait speed has been considered the most relevant kinematic variable of gait ${ }^{7,28}$ and a good predictor of functional performance ${ }^{14}$, cardiovascular health and the ability to perform activities of daily living in elderly people ${ }^{18}$. 
Table 3. Results of multiple linear regression analysis to predict usual gait speed in the 10-meter walking test for middle-aged and older subjects.

\begin{tabular}{lccccc}
\hline & Coefficient $\beta$ & S.E. & Minimum & Maximum & P value \\
\hline Constant & 1.662 & 0.109 & 1.405 & 1.839 & $<0.001$ \\
\hline Age (years) & -0.008 & 0.002 & -0.011 & -0.004 & $<0.001$ \\
\hline Gender $^{\star}$ & 0.115 & 0.042 & 0.032 & 0.198 & 0.007 \\
\hline
\end{tabular}

Gait speed in $\mathrm{m} / \mathrm{s}=1.662-(0.008 \times$ age $)+\left(0.115 \times\right.$ Gender); ${ }^{2}=0.246$ (estimated standard error $\left.=0.209 \mathrm{~m} / \mathrm{s}\right)$. S.E. $=$ standard error; C.I. =confidence interval. ${ }^{*}$ Gender Factor: men=1; women=0.

Due to the analysis of equations developed in previous studies for the prediction of usual gait speed ${ }^{20,32}$, differences between the gait speed means and foreign patterns were expected. The results can be explained, partly, by the insertion of different anthropometric and kinematic spatial and temporal parameters in the regression models used to predict usual gait speed. In the present study, the variables gender and age were selected as determinants of usual gait speed. In the study carried out by Bohannon, Andrews and Thomas $^{20}$, the best equation developed for prediction of usual gait speed $\left(\mathrm{R}^{2}=131\right)$ included, besides gender, body mass and hip flexor strength in the following model: $\mathrm{VM}=149.65$ - (7.65*gender) ( 0.04 * hip flexor strength $)+(0.21$ * body), while Lusardi, Pellecchia and Schulman ${ }^{32}$ formulated a regression model that estimates usual gait speed based exclusively on age and the use of assistive devices for walking, according to the equation $\mathrm{VM}=2.57-(0,02$ * age in years) - $\left(0.28^{*}\right.$ assistive devices [yes $\left.\left.=1, \mathrm{no}=0\right]\right),\left(\mathrm{R}^{2}=0.63\right)$. The different variables used to predict usual gait speed indicate that, besides limitations regarding standardization of the methodology used in the studies, anthropometric factors and gait kinematic characteristics may influence the values of usual gait speed differently in different populations.

The aforementioned studies clearly show the need for reference values that could be used to evaluate the gait of individuals with neuromotor disorders and to help define diagnosis and prognosis for these individuals. Given the trend of population aging and the increased prevalence of locomotion disorders, there is a need to determine a normal pattern, especially for older individuals. Moreover, the results for usual gait speed observed in the present study were significantly lower than those observed in foreign populations, which indicates the need for research regarding reference values for this variable in the Brazilian population.

The present study has some limitations. It is not possible to affirm to what extent the observed results were representative for the Brazilian population. A similar limitation was described by Steffen, Hacker and Mollinger ${ }^{21}$, who investigated patterns of usual gait speed in a sample of Americans. The low number of volunteers evaluated, although sufficient for multiple regression analysis, may have been insufficient for comparisons between different age groups and might have resulted in a $\beta$ error in the statistical analysis.

\section{Conclusions : :}

It was observed that age and gender are variables that could significantly influence the values of usual gait speed in healthy middle-aged and elderly adults, since much of the gait speed variability was adequately explained by these variables. Furthermore, the significant difference observed between usual gait speed in the Brazilian sample and the speeds described in foreign populations suggests the need for reference values based on demographic and anthropometric characteristics of the Brazilian population.

\section{Acknowledgments $: \therefore$.}

To the kinesiology students of the Physical Therapy course of the Universidade Federal dos Vales do Jequitinhonha e Mucuri (UFVJM), Diamantina, MG, Brazil, for contributing to the data collection.

\section{References: : :}

1. Podsiadlo D, Richardson S. The timed "Up \& Go": a test of basic functional mobility for frail elderly persons. J Am Geriatr Soc. 1991;39(2):142-8.

2. Chau T. A review of analytical techniques for gait data. Part 2: neural network and wavelet methods. Gait Posture. 2001;13(2):102-20.

3. Grabiner PC, Biswas ST, Grabiner MD. Age-related changes in spatial and temporal gait variables. Arch Phys Med Rehabil. 2001;82(1):31-5.

4. Hageman PA. Gait characteristics of healthy elderly: a literature review. Issues Aging. 1995;18:14-8.
5. Verghese J, Holtzer R, Lipton RB, Wang C. Quantitative gait markers and incident fall risk in older adults. J Gerontol A Biol Sci Med Sci. 2009;64A(8):896-901.

6. Bohannon RW. Population representative gait speed and its determinantsJ Geriatr Phys Ther. 2008;31(2):49-52.

7. Kim MJ, Yabushita N, Kim MK, Matsuo T, Okuno J, Tanaka K. Alternative items for identifying hierarchical levels of physical disability by using physical performance tests in women aged 75 years and older. Geriatr Gerontol Int. 2010;10(4):302-10. 
8. Studenski S, Perera S, Wallace D, Chandler JM, Duncan PW, Rooney E, et al. Physical performance measures in the clinical setting. J Am Geriatr Soc. 2003;51(3):314-22.

9. Al-Obaidi S, Wall JC, Al-Yaqoub A, Al-Ghanim M. Basic gait parameters: A comparison of reference data for normal subjects 20 to 29 years of age from Kuwait and Scandinavia. J Rehabil Res Dev. 2003;40(4):361-6.

10. Guralnik JM, Ferrucci L, Simonsick EM, Salive ME, Wallace RB. Lower-extremity function in persons over the age of 70 years as a predictor of subsequent disability. N Engl J Med. 1995;332(9):556-61.

11. Rantanen T, Guralnik JM, Ferrucci L, Penninx BW, Leveille S, Sipilä S, et al. Coimpairments as predictors of severe walking disability in older women. J Am Geriatr Soc. 2001;49(1):21-7.

12. Markides KS, Black SA, Ostir GV, Angel RJ, Guralnik JM, Lichtenstein M. Lower body function and mortality in Mexican American elderly people. J Gerontol A Biol Sci Med Sci. 2001;56(4):M243-7.

13. Watson MJ. Refining the ten-metre walking test for use with neurologically impaired people. Physiotherapy. 2002;88(7):386-97.

14. Hollman JH, Beckman BA, Brandt RA, Merriwether EN, Williams RT, Nordrum JT. Minimum detectable change in gait velocity during acute rehabilitation following hip fracture. J Geriatr Phys Ther. 2008;31(2):53-6

15. Sandercock P. Walking speed as a measure of disability. Nurs Times. 1991;87(46):45.

16. Maki BE. Gait changes in older adults: Predictors of falls or indicators of fear. J Am Geriatr Soc. 1997:45(3):313-20

17. Ostir GV, Kuo YF, Berges IM, Markides KS, Ottenbacher KJ. Measures of lower body function and risk of mortality over 7 years of follow-up. Am J Epidemiol. 2007;166(5):599-605.

18. Hardy SE, Perera S, Roumani YF, Chandler JM, Studenski SA. Improvement in usual gait speed predicts better survival in older adults. J Am Geriatr Soc. 2007;55(11):1727-34.

19. Oberg T, Karsznia A, Oberg K. Basic gait parameters: reference data for normal subjects,10-79 years of age. J Rehabil Res Dev. 1993;30(2):210-23.

20. Bohannon RW, Andrews A W, Thomas MW. Walking speed: reference values and correlates for older adults. J Orthop Sports Phys Ther. 1996;24(2):86-90.

21. Steffen TM, Hacker TA, Mollinger L. Age- and gender-related test performance in communitydwelling elderly people: Six-Minute Walk Test, Berg Balance Scale, Timed Up \& Go Test, and gait speeds. Phys Ther. 2002;82(2):128-37.

22. Baecke JA, Burema J, Frijters JE. A short questionnaire for the measurement of habitual physical activity in epidemiological studies. Am J Clin Nutr. 1982;36(5):936-42.

23. Bohannon RW. Comfortable and maximum walking speed of adults aged 20-79 years: reference values and determinants. Age Ageing. 1997;26(1):15-9.

24. Samson MM, Crowe A, de Vreede PL, Dessens JA, Duursma SA, Verhaar HJ. Differences in gai parameters at a preferred walking speed in healthy subjects due to age, height and body weight Aging (Milano). 2001;13(1):16-21.

25. Singh MA. Exercise and aging. Clin Geriatr Med. 2004;20(2):201-21.

26. Ostrosky KM, VanSwearingen JM, Burdett RG, Gee Z. A comparison of gait characteristics in young and old subjects. Phys Ther. 1994;74(7):637-44

27. Callisaya ML, Blizzard L, Schmidt MD, McGinley JL, Lord SR, Srikanth VK. A population-based study of sensorimotor factors affecting gait in older people. Age Ageing. 2009;38(3):290-5

28. Murray MP, Kory RC, Clarkson BH. Walking patterns in healthy old men. J Gerontol. 1969;24(2):169-78

29. Elble RJ, Thomas SS, Higgins C, Colliver J. Stride-dependent changes in gait of older people. $J$ Neurol. 1991;238(1):1-5.

30. Woo J, Ho SC, Yu AL. Walking speed and stride length predicts 36 months dependency, mortality, and institutionalization in Chinese aged 70 and older. J Am Geriatr Soc. 1999;47(10):1257-60.

31. Cesari M, Kritchevsky SB, Penninx BW, Nicklas BJ, Simonsick EM, Newman AB, et al. Prognostic value of usual gait speed in well-functioning older people--results from the Health, Aging and Body Composition Study. J Am Geriatr Soc. 2005;53(10):1675-80.

32. Lusardi MM, Pellecchia GL, Schulman M. Functional Performance in Community Living Older Adults. J Geriatr Phys Ther. 2003;26(3):14-22. 